\title{
THE RELATIONSHIP BETWEEN GENDER DISCRIMINATION PERCEPTION AND MOBBING FROM THE PERSPECTIVE OF EUROPEAN UNION AND TURKEY
}

\author{
DOI: 10.17261/Pressacademia.2019.1154 \\ RJBM-V.6-ISS.4-2019(1)-p.213-231
}

\section{Nilufer Yoruk Karakilic}

Afyon Kocatepe University, Department of Management and Organization, ANS Campus, Afyonkarahisar, Turkey. nilyoruk@aku.edu.tr, ORCID: 0000-0002-6609-4068

\begin{tabular}{l}
\hline Date Received: September 20, $2019 \quad$ Date Accepted: December 5, 2019 \\
\hline To cite this document \\
Karakilic, N.Y.,(2019). The relationship between gender discrimination perception and mobbing from the perspective of European Union \\
and Turkey. Research Journal of Business and Management (RJBM), V.6(4), p.213-231. \\
Permemant link to this document: $\underline{\text { http://doi.org/10.17261/Pressacademia.2019.1154 }}$ \\
Copyright: Published by PressAcademia and limited licenced re-use rights only.
\end{tabular}

\section{ABSTRACT}

Purpose - Discrimination is an individual's exposure to unfair behaviors due to some factors such as gender, age, race, income and social status. The perception of gender-based discrimination was evaluated from the perspective of European Union and Turkey and it was aimed to explain the relationship between the perception of gender-based discrimination and mobbing in this study.

Methodology - In this study, a survey was conducted to the academicians working at Afyon Kocatepe University. For the validity and reliability of the survey Structural Equation Model was tested with SPSS 16 and AMOS 19 programmes and the hypotheses were tested by AMOS 19 programme. In the study analyzed whether the perception of gender discrimination increased the emotional violence in workplaces or not, in other words its relation with mobbing.

Findings- According to the outputs of Structural Equation Model, the presence of the effect of the perception of hostile gender discrimination was identified; however, it was revealed that the perception of benevolent gender discrimination had no effect on mobbing.

Conclusion- In the studies to decrease the perception of gender discrimination in society should be conducted in order to prevent the incidence of mobbing. The most important step to take for EU countries and Turkey about mobbing is to legislate in this field. Legal practices and sanctions to prevent mobbing should be implemented. It is also important to create awareness in the society in this issue. This awareness should be supported by mass media to enchance the awareness.

Keywords: Gender disrimination, mobbing, structural equation model, European Union countries, Turkey. JEL Codes: J16, M50, M54

\section{INTRODUCTION}

Gender discrimination includes all types of gender-based discriminations, exclusions and restrictions, which aim to prevent and restrict the use of human rights and freedoms for women based on the equality of women and men in political, economic, social, cultural, personal or other fields. Women are exposed to gender-based discrimination in both business and social life and they need to fight against to overcome it. In fact, there is a need to focus on gender discrimination within the scope of Constitution based on providing equal rights and freedoms to all humanbeings and prevent it. Discrimination is all types of behaviors intending to prevent rights and freedoms to be benefited equally by all humanbeings. Gender discrimination is one of the discrimination types and it is a phenomenon that needs to be eliminated due to its various negative effects on both social and business life. It is a situation preventing a person from certain powers and responsibilities due to the gender despite being the competent of the work, in other words depriving someone from some rights due to the gender and some examples can be seen in both European countries and Turkey.

The rest of this paper contains five sections. Section 2 provides literature review on gender discrimination and mobbing. Section 3 includes the relatıonshıp between the perceptıon of gender discrımınatıon and mobbıng in European Unıon countries and Turkey. Section 4 describes our data and analyses that consist of sample selections, data, and variables 
measurement. Section 4 reports the findings of this study including descriptive statistics, correlation analysis, and Structural Equation Model for hypothesis testing. Section 5 recomendation and concludes.

\section{CONCEPTUAL FRAMEWORK}

Discrimination is defined as behaving someone in an undeserved way and in a manner different from others due to various reasons. Discrimination may happen in various ways. There may be discrimination for many reasons such as language, religion, race and physical appearance, place of birth, financial status, and social status of a person. In the study gender discrimination was evaluated.

Mobbing is a concept defined as emotional violence as well as it is cruel treaments and behaviours on people in workplaces. Mobbing is a social phenomenon that is analyzed in the whole world and needs to be prohibited and prevented.

\subsection{Gender Discrimination}

When we look at the literature, we can see lots of studies on gender discrimination and its reasons. Stainback et al. (2011) researched the reasons of social gender discrimination. Öztan (2004) in his study researched the regulations needed to be done in order to create and develop discrimination policies to ensure social gender equality. Sarı (2017) researched the role of gender-based discrimination in business and political life of women in Turkey. Şen (2018) in his study evaluated the genderbased wages equality within the scope of European Union and Turkey. Konuk (2014) researched the gender discrimination from the perspective of European Union Law. Çiftçi (2010) in his study concluded that income difference between men and women affected the tendency for labour force participation through the econometrics practice in 15 European countries and Turkey. Sipe et al. (2016) in their studies tried to determine the perception of gender discrimination in the research conducted between 2006 and 2013. Khan et al. (2018) measured the gender discrimination perceptions of university students. In the survey study with 150 students from different countries they concluded that the gender factor made a significant difference in the perception of gender discrimination; however, education and age factors did not. Skewes et al. (2018) researched the relationship between the perception of gender equality and the gender role in the surveys and they conducted the study in two different countries. Snizek and Neil (1992) in their study analyzed the underlying processes of gender discrimination. In the survey in Australia with 625 female and 512 male participants they concluded that $37 \%$ of the women and $41 \%$ of the men experienced the discrimination everyday. Sipe et al. (2009) tried to determine the expected gender discrimination perception of students. In the survey that they conducted with 1373 university students they argued that the perception of female students would be higher. Zeher (2011) focused on the importance of gender inequality and gender discrimination. He stated that organizational factors and stereotyped prejudices about gender may cause the discrimination. After analyzing 209 court files about gender discrimination, he emphasized the effects of cultural, structural and interactional processes on gender discrimination.

What makes Ambivalent Gender Discrimination Theory remarkable in the field of discrimination is the perception of benevolent and hostile gender discrimination. A patriarchal understanding regards women as weak and powerless; and therefore, they need to be protected by men who are stronger than women and suggests that women need to be helped and supported economically, and it is dominant in benevolent gender discrimination. There are more negative attitudes which argue that women are not sufficiently grateful for what men do for them in hostile gender discrimination in which a dominant patriarchy is effective. Patriarchy serves to men's dominance in the society no matter how gender discrimination occurs in the society either in a hostile or benevolent manner. This relationship in a hostile gender discrimination works as intersexual competative differentiation; however, it works in benevolant gender discrimination as intersexual complementary differentiation. Establishing the superiority of men to women by comparing them and satisfying personal emotions by exaggerating this superiority include intersexual competative differentiation. The differences between men and women are presented in order to trivialize women. However, intersexual complementary differentiation regards women and men as two parts complementing each other. It presents the traditional sexual differences by accepting the idea that women and men need each other. With the thought that men have to work outside, but women have to work inside it legalizes the traditional gender roles and the distribution of these roles under the cover of doing a favour for women. Finally, heteosexuality is one of the important resources of gender discrimination. The most effective way that heterosexuality uses in order to be a resource of gender discrimination is that a romantic relationship to be established with the opposite sex is the primary condition for the happiness in life (Glick and Fiske, 1996: 493). 


\subsection{Mobbing}

When the word mobbing is ethimologically analyzed, "mob" comes from the word "mobile vulgus" which means "the fickle crowd" in Latin. The concept of mobbing was used for the first time by Konrad Lorenz in 1960's in order to define the behaviors of animals to throw away a foreign person or a hunting enemy. In 1970, Swedish Dr. Peter-Paul Heinemann studied on the bullying and tyranny behaviors among children and used the word mobbing. (Davenport, et al., 2003: 3). It is known that the word mobbing in business life was used for the first time by Swedish industrial psychologist Heinz Leymann. We can see that Leyman used this concept as a result of the findings obtained from his studies among the employees. This kind of behaviors in business life has not been recognized and defined by anybody else before Leymann. Therefore, Leymann's views and studieshave formed a basis for the studies on mobbing behaviors in workplace around the world. Leymann has not only indicated the presence of mobbing behavior in workplaces, but also emphasized the specific qualities of the behavior, its incidence, mostly affected people from the violence and potential psychological consequences (Tınaz, 2006: 14).

Leymann (1990) who had the most important studies on mobbing in literature revealed the presence of mobbing in Sweden and in other countries in his study. Leymann (1996) studied on mobbing in Sweden and analyzed the factors that would be related with mobbing. Koonin and Green (2007) have identified the causes of mobbing in the workplace and suggested solutions to eliminate it. Gül et al. (2011) studied mobbing and burnout syndrome on academicians. Stefanovic (2012) in his study examined the role of trade unions in the prevention process of mobbing. Sobre-Denton (2012) analyzed mobbing in terms of race, class and gender. Tomic (2012) tried to determine the level of mobbing in his study on 369 participants. They determined that $80,87 \%$ of the survey participants were exposed to mobbing at least once. Jenkins et al. (2012) in their study questioned the reasons of mobbing by focusing on the perspectives of mobbed people. Escartin et al. (2013) analyzed the bullying at work in their study on 494 employees in 19 different organizations.

Mulder et al. (2017) identified the concept of gender as an important factor affecting the mobbing process. Nielsen and Einarsen (2018) analyzed the reasons and consequences of mobbing. Şenol et al. (2015) tried to determine the level of exposure to mobbing in the academic environment. Çögenli and Döner (2015) focused on mobbing to the academics in Turkey. Sarıçam (2016) investigated the relationship between the meaning of work and the concept of mobbing and social trust and satisfaction. Baillien et al. (2018) investigated the relationship between organizational change process and mobbing. McCormack et al. (2018) analyzed the relationship between gender and emotional violence. In their study in Uganda on 125 teachers they determined the relationship between gender and bullying at work. Yanık (2018) evaluated the underlying reasons of reactive and unreactive behaviours of individuals exposed to emotional violence at work against intimidation. Aşkın and Aşkın (2018) researched the incidence, direction, frequency and reasons of sexist mobbing to women in business life. Halaç and Güloğlu (2019) analyzed the effects of mobbing behaviour called as psychological intimidation on employees' efficiency. They carried out fieldwork on administrive staff in SMEs manufacturing in Manisa Organized Industrial Zone and determined that efficiency level of the employees exposed to mobbing increased unlike the expectations. Kement and Batga (2016) analyzed the effect of mobbing on organizational commitment.

Mobbing is characterised as the systematic psychological abuse or humiliation of a person by an individual or a group in workplaces in order to damage his/her reputation, honour, human dignity and integrity, and ultimately drive him/her to quit the job (www.eurofound.europa.eu, 2007). According to Leymann, mobbing is not just about every day quarrels, disputes, frictions, ironic remarks, sarcasm, mocking and so on. But it is about doing these over and over, repeatedly, so that they will have a result, eventually, it will become disturbing, painful and even destructive (Dragomır, 2018: 410). Mobbing is also called as emotional violence in literature and there will be its reflections in all workplaces. Mobbing in workplaces is the most severe form of the violations of labor rights, social, economic and fundamental human rights in general. It gives serious and permanent psychological and health damages to its victims and also causes economic damage to companies or institutions and the countries' economies in general (Stefanovic, 2012:401). Mobbing as emotional violence in workplaces takes place in three different categories on social, organizational and individual levels (McCormack et al., 2018:265). Swedish psychologist Leymann, who raised the topic of psychological abuse to be discussed the fields of industrial and organizational psychology, defined mobbing as "directing a systematic" hostile and unethical communication. Others by a person or more than one person and included the expression of "psychological terror" (Leymann, 1996: 165). Leymann stated that mobbing can be performed at work both by the managers and the colleagues (Leymann, 1990:119).

\section{THE RELATIONSHIP BETWEEN THE PERCEPTION OF GENDER DISCRIMINATION AND MOBBING IN EUROPEAN UNION COUNTRIES AND TURKEY}

In the literature, many studies have been conducted to reveal mobbing and gender discrimination in many countries. For example; Carnero et al. (2010) investigated the reasons of mobbing in Spain and emphasized the importance of gender in 
mobbing. Poussard et al. (2018) found that the main reason for mobbing was discriminatory elements such as differences in political and religious views. Kovacic et al. (2017) analyzed whether mobbing depended on gender, age and status. Buttigieg et al. (2011) investigated the relationship between discrimination and bullying and mobbing. In their study they identified the presence of common determiners between discrimination and bullying. Kara et al. (2018) tried to determine the effects of mobbing on female employees. They studied on 373 women working in a five star hotel in Turkey. They concluded that the mobbing behaviour of the managers decreased the quality of life of the female employees. Salin (2003) evaluated the literature in the field of mobbing.

A number of regulations have been made by the EU Parliament on mobbing and gender discrimination in EU countries. Resolution A5-0283/2001 of the EU Parliment recommends the EU member states which modify their respective legislations to include the phenomena of mobbing and sexual abuse in the workplace. According to the resolution, harmonising the definition of the 'mobbing' term is the most successful approach in order to achieve this goal. The European Parliament Report on harassment in the workplace (2001/2339 INI) defines certain responsibilities for the Committee on Employment and Social Affairs. Additionally, the report includes a recommendation of the Committee for Women's Rights and Gender Equality, which addresses to the member states to impose on the public and private sectors, and the social partners the duty to define a policy in the prevention of mobbing (Stefanovic, 2012: 403).

Among the initiatives to legally regulate mobbing at EU level, the Directive of European Parliament and Council dated on 23rd September 2002 amending the directive on the implementation of the principle of equal treatment among women and men in employment, vocational education, promotion and working conditions related to equality. In this directive the member states are requested to take the necessary measures to prevent all types of abuses in workplaces. The statement that member countries will accept sexual abuse as a gender-based discrimination with the adoption of this directive is included in the directive (Ergin, 2013: 69).

When we analyze mobbing, according to study results conducted in UK, $53 \%$ of the employees were exposed to mobbing and $78 \%$ of them witnessed it. According to the findings of a statistical study conducted in Sweden, mobbing was the reason for $10-15 \%$ of suicides committed within one year. We can see in registries that hundred of thousands of mobbing victims in Sweden and Germany retired early and they were hospitalized and treated in psychiatry clinics. It is reported that there are more than one million mobbing victims in Italy. Various studies on the fight against mobbing have been carried out in European Union countries. Unions in European Union member countries conduct very strong lobbying activities so that the laws against mobbing can be implemented. In Scadinavian countries mobbing is included in laws as a direct crime. Among these countries the greatest development about mobbing is in Sweden. Mobbing is defined as a crime in Sweden with Business Safety and Worker's Health Law issued in 1994. The articles indicating that mobbing was the violation of collective agreement were included in collective labour agreements. In Germany mobbing victims may offer early retirement. There are civil centres that mobbing victims would request help from around the country. Mobbing is a legal crime in France and it is provided for one-year imprisonmentand 15000 Euros fine. In France "victimologie" professorship was established about mobbing victims in university in 1994. In Italy laws against mobbing were legally issued and the problems occuring as a result of mobbing were included in the scope of work accidents (Tınaz, 2006: 15).

Countries such as the UK resisted introducing specific legislation against bullying despite pressure from anti-bullying advocacy groups, leaving the legal situation somewhat ambiguous. With no particular legislation addressing the issue, when a victim of bullying pursues a course of legal action, one or more general legal provisions could form the basis of the case, including among others (Policy Department for Citizens Rights' and Constitutional Affairs, 2018: 49).

The European Working Conditions Survey (EWCS) by the European Foundation is the most comprehensive survey of the prevalence of bullying at work across the EU based on interviews with about 1,000 respondents in each country. According to the 6th EWCS in 2015, 5\% of the respondents reported being subjected to bullying/harassment over the last twelve months. The reported exposure was somewhat higher in Western and in Northern countries compared to Southern and Eastern countries. Exposure to bullying was common in France, Luxembourg, Ireland, Belgium and the Netherlands most. The lowest prevalence rates were found in Bulgaria, Portugal, Hungary and Greece (Policy Department for Citizens Rights' and Constitutional Affairs, 2018: 15).

Table 1: Prevalence of Bullying and Sexual Harassment at Work in EU Countries

\begin{tabular}{|l|c|c|c|c|c|c|}
\hline Country & \multicolumn{3}{|c|}{ Bullying/Harassment } & \multicolumn{3}{c|}{ Sexual Harassment } \\
\hline France & $12.2 \%$ & $13.5 \%$ & $11.0 \%$ & $0.4 \%$ & $0.6 \%$ & $0.2 \%$ \\
\hline Ireland & $8.1 \%$ & $9.2 \%$ & $7.2 \%$ & $0.7 \%$ & $1.3 \%$ & $0.1 \%$ \\
\hline
\end{tabular}




\begin{tabular}{|l|l|l|l|l|l|l|}
\hline Belgium & $7.5 \%$ & $8.7 \%$ & $6.5 \%$ & $0.8 \%$ & $1.1 \%$ & $0.5 \%$ \\
\hline Netherlands & $7.1 \%$ & $7.7 \%$ & $6.6 \%$ & $2.4 \%$ & $4.2 \%$ & $0.8 \%$ \\
\hline Austria & $5.2 \%$ & $6.5 \%$ & $4.2 \%$ & $1.2 \%$ & $1.8 \%$ & $0.6 \%$ \\
\hline Filland & $4.9 \%$ & $7.2 \%$ & $2.7 \%$ & $1.1 \%$ & $1.9 \%$ & $0.3 \%$ \\
\hline Germany & $4.8 \%$ & $5.0 \%$ & $4.5 \%$ & $1.1 \%$ & $2.0 \%$ & $0.4 \%$ \\
\hline UK & $4.6 \%$ & $5.3 \%$ & $4.1 \%$ & $0.8 \%$ & $1.5 \%$ & $0.3 \%$ \\
\hline Sweden & $4.5 \%$ & $5.4 \%$ & $3.7 \%$ & $1.9 \%$ & $3.4 \%$ & $0.6 \%$ \\
\hline Denmark & $4.0 \%$ & $5.1 \%$ & $3.0 \%$ & $1.0 \%$ & $1.5 \%$ & $0.6 \%$ \\
\hline Romania & $4.0 \%$ & $5.1 \%$ & $3.0 \%$ & $0.1 \%$ & $0.0 \%$ & $0.2 \%$ \\
\hline Spain & $3.3 \%$ & $3.1 \%$ & $3.4 \%$ & $0.5 \%$ & $0.6 \%$ & $0.3 \%$ \\
\hline Italy & $2.9 \%$ & $2.9 \%$ & $3.0 \%$ & $0.1 \%$ & $0.1 \%$ & $0.1 \%$ \\
\hline Poland & $1.0 \%$ & $1.1 \%$ & $0.8 \%$ & $0.3 \%$ & $0.5 \%$ & $0.0 \%$ \\
\hline Portugal & $0.9 \%$ & $1.0 \%$ & $0.8 \%$ & $0.9 \%$ & $0.8 \%$ & $0.9 \%$ \\
\hline
\end{tabular}

Source: (Policy Department for Citizens Rights' and Constitutional Affairs, 2018: 74).

All women and men were subjected to bullying and sexual harassment during the course of work over the last 12 months (\%).

As shown in Table 1; in 2018, the highest exposure to mobbing rate occurred in France, Ireland, and Belgium; however, the lowest exposure rate was in Portugal.

The countries in European Union have regulations on gender discrimination and mobbing supported by laws. These regulations are as follows;

Germany - All people are equal before the law. Men and women have equal rights. The state encourages to actually ensuring men and women equality and making efforts to eliminate the disadvantages. Nobody can be mistreated and no privileges can be granted to anyone due to their gender, blood, race, language, homeland and origin, belief, religion or political views. Nobody can be mistreated due to handicaps and disabilities (Eroğlu, 2011: 3).

Belgium - Belgium is of interest as Belgian legislation developed in a somewhat different way from most other countries. The Welfare Act (or Welfare Law) was enacted in 1996, and it has been amended several times since then. In 2002 an amendment was enacted to combat 'undesirable behavior' in the workplace (bullying, harassment including sexual harassment, and violence). In 2014 the Prevention of All Psychosocial Risks at Work came into force. The new Act is not limited to bullying and sexual harassment but covers all psychosocial risks that could lead to occupational stress. The Act puts harassment in a more general framework of psychosocial risks and states that employers must recognise harassment like any other risk to employees' health (Policy Department for Citizens Rights' and Constitutional Affairs, 2018: 48).

Bulgaria - All citizens are equal before the law. No privileges or restrictions will be granted to anyone in rights on the grounds of race, nationality or social origin, ethnical identity, gender, education, opinion, political connections, personal or social status or property status (Eroğlu, 2011: 3).

Finland - Nobody will be discriminated from others because of gender, age, origin, language, religion, belief, opinion, health, handicap or another reasons related with a person without any acceptable reason (Eroğlu, 2011: 3).

Finland is a typical example of countries which primarily address bullying (and harassment) via occupational safety and health legislation. Thus, The Finnish Occupational Health and Safety Act of 2003 include a special section on harassment at work. It is reactive by nature and obliges the employers to take action after being aware of the matter. The section also covers inappropriate behaviour by third parties which means employers have a duty to take action also in those cases where the perpetrator is a third party. The Act also makes it clear that employees themselves have a duty to refrain from harassment. Moreover, it contains particular sections about prevention which is also applied to bullying and harassment, including risk assessment and the employer's general duty of care (Policy Department for Citizens Rights' and Constitutional Affairs, 2018: 48).

United Kingdom - In the UK, there is no specific legal framework for preventing and combating psychological harassment in workplaces. However, general legal regulations provide indirect protection against psychological harassment in workplaces. These are mainly; The Health and Safety At Work Act (1974), the Employment Rights Act (1996), the Protection From Harassment Act (1997) and the Equality Act (2010) (Çukur, 2016: 58). 
France - According to French Social Modernization Law of 2002; "Mobbing is psychological violence that occurs while performing certain activities;" (Tomic, 2012: 244)

It was adopted for the first time by the law in 1992 as only limited with superior-subordinate relationship. French Social Modernization Law adopted in France on 19th December, 2001 was implemented on 17th January, 2002. With this law new articles were added to French Criminal Code and Labour Law. Therefore, mobbing in workplaces was specially regulated as sexual harassment in both Labour Law and Criminal Code. Therefore, France has become a country with the most comprehensive regulation on mobbing in workplaces. The conciliation method that would be carried out by a mediator out of the enterprise was foreseen in the law in case of moral harassment. The role of the mediator is to solve the problem between parties through conciliation (Kaya, 2015:378)

In France, workplace bullying, which is known as 'moral harassment', is regulated under both the Labour Law (2008, amended 2016) and the Criminal Code (2009). The Labour Law applies to both private and public employees, and addresses moral harassment, discrimination, and professional equality between men and women. The Criminal Code imposes a criminal sanction for bullying (Policy Department for Citizens Rights' and Constitutional Affairs, 2018: 48).

Ireland - Nobody would be excluded from Irish nationality and citizenship due to gender. The age of eighteen and are not regarded as noncompetent by the law and comply with the provisions of law regulating the election of the members of the House of Representatives have the right to vote in the elections of the members of the House of Representatives (Eroğlu, 2011).

Spain - The Spanish are equal before the law and can in no way be discriminated due to birth, race, gender, religion, opinion or any personal, social conditions or situations (Eroğlu, 2011).

Sixteen percent of workers in the European Union (EU) suffer psychological harassment or"mobbing" on the job, according to study by the University of Alcalá de Henares, in Spain (http://www.ipsnews.net/2002/10/labour-rights-spain-fightingbullying-in-the-workplace/).

Sweden - No law or provision may include a negative treatment to anybody due to ethnical origin, colour or a concern with minority group because of other conditions or sexual orientation (Eroğlu, 2011).

Heinz Leyman has found the topic of mobbing in workplaces in this country. Mobbing occurs in Sweden especially among colleagues. It was determined in a study that mobbing occured $44 \%$ of rate among the people with the same status, $37 \%$ from the top to down and $9 \%$ from down to top. It was observed that $55 \%$ of the women and $45 \%$ of the men were the victims of mobbing in Sweden. Sweden is the first country which has made special legislative regulations against mobbing (Kaya, 2015: 377).

Norway - Norway, which follows a similar way with Finland, is of interest for several reasons. First, the Norwegian Work Environment Act makes it explicit that it is the employer's responsibility to protect employees against exposure to adverse physical and mental strain'. Second, it implicitly grades possible offences by highlighting various forms of adverse effects including 'improper conduct', 'breach of employees' dignity and respect' and 'harassment'. Third, the dynamic aspects of the law are emphasized that 'standards shall be continuously developed and improved in accordance with developments in society'. (Policy Department for Citizens Rights' and Constitutional Affairs, 2018: 48).

Italy - All the citizens are equal before the law and socially equal without any discrimination in terms of gender, race, language, religion, political view, personal and social conditions (Eroğlu, 2011). There is no specific legislation related with mobbing or other forms of harassment. But a body of case law has been developed to clearly establish a definition for an unacceptable behaviour and present what steps an employer should take both to prevent such conduct and deal with problems when they occur. (www.fedee.com/kb/italy-discrimination/). In Italy, targeted research and studies on mobbing started in the 1990s. In 1998, the European Foundation for the Improvement of the Living and Working Conditions estimated that, in Italy, about $4.2 \%$ of workers were victims of mobbing. According to data compiled by national experts, at present, the proportion varies between $4 \%$ and $6 \%$ of the work force, i.e. between 1 million and 1.5 million workers (www.eurofound.europa.eu, 2007)

Poland - Mobbing was firstly regulated legally in Poland with the amendment in law which was implemented on 1st January, 2004. In accordance with the 1st paragraph of 94th article of Polish Labour Law, employers are responsible for preventing 
mobbing. Although the definition of mobbing in Polish Labour Law is very broad, illegality of the behaviour of the perpetrator and the importance of health aspect of mobbing are not sufficiently emphasized (Kaya, 2015: 379). Poland's Supreme Court rendered a decision on 3.08.2011 (case file no. I PK 35/11) in which it emphasised that preventing bullying at the workplace is an obligation to exercise due diligence. This decision is of significance for employers, as it means that when an employer proves that it undertook real action against bullying (rules, trainings), it may be absolved from liability (https://www.schoenherr.eu/publications/publication-detail/poland-internal-employers-regulations/).

Romania - Romania is the common and inseperable homeland of all citizens without any discrimination in terms of race, nationality, ethnical origin, language, religion, gender, opinion, political commitment, property and social origin (Eroğlu, 2011).

Turkey - Everybody is equal before the law without any discrimination due to the reasons such as language, race, colour, gender, policial view, philosophical belief, religion, sect and so on.

When determining the position of women in Turkish society, three main periods as pre-Islamic and post-Islamic and Republican Turkey can be analyzed. In the pre-Islamic period, in Turks there is almost no social gender discrimination targeting women. Women are almost equal to men. They have the right to comment on the management of country with Hakan. They manage home. Physical violence to women by men cannot be observed in Turks. Children are highly valuable in old Turks. When a woman has a child, she becomes a beloved person in the family gradually. Communication and meeting between men and women are completely free in Altai people. During the conservation between young men and women, women do not think to cover her face. Women are not behind the men and isolated from the society in private, family and social life and even in political platform. They are within the life with men and visible in the eye of society (Bingöl, 2014:111). With the acceptence of Islam by Turks, Byzantine, Arabic and Iranian cultures had effects on Turkish culture. Different interpretation of Islam and Islamic ethics actually highly sensitive about women and bestow rights to them changed the position of women in society. This process led women to be behind men and even enabled men to have a chance to marry with four women. Foundation of Turkish Republic has enabled to establish the fundamentals of social gender equality. The republic period has brought rights for women through many legislative regulations (Bingöl, 2014:112). However, along with the components reflecting to the culture socially women have not obtained the equality they deserve even today.

Table 2: Gender discrimination and mobbing regulations of EU countries

\begin{tabular}{|l|l|}
\hline Country & Gender Discrimination and Mobbing Regulation \\
\hline Germany & $\begin{array}{l}\text { All people are equal before the law. Nobody can be mistreated and no privileges can be granted to anyone due } \\
\text { to their gender, blood, race, language, homeland and origin, belief, religion or political views. }\end{array}$ \\
\hline Belgium & $\begin{array}{l}\text { Belgian legislation developed in a somewhat different way from most other countries. In } 2002 \text { an amendment } \\
\text { was enacted to combat 'undesirable behaviour' in the workplace (bullying, harassment including sexual } \\
\text { harassment, and violence). }\end{array}$ \\
\hline Bulgaria & $\begin{array}{l}\text { All citizens are equal before the law. No privileges or restrictions will be granted to anyone in rights on the } \\
\text { grounds of race, nationality or social origin, ethnical identity, gender, education, opinion, political connections, } \\
\text { personal or social status or property status }\end{array}$ \\
\hline Finland & $\begin{array}{l}\text { Nobody will be discriminated from others because of gender, age, origin, language, religion, belief, opinion, } \\
\text { health, handicap or another reasons related with a person without any acceptable reason. Finland is a typical } \\
\text { example of countries which primarily address bullying (and harassment) via occupational safety and health } \\
\text { legislation. }\end{array}$ \\
\hline $\begin{array}{l}\text { United } \\
\text { Kingdom }\end{array}$ & $\begin{array}{l}\text { There is no specific legal framework for preventing and combating psychological harassment in workplaces. } \\
\text { However, general legal regulations provide indirect protection against psychological harassment in } \\
\text { workplaces. }\end{array}$ \\
\hline
\end{tabular}




\begin{tabular}{|c|c|}
\hline France & $\begin{array}{l}\text { Workplace bullying, which is known as 'moral harassment', is regulated under both the Labour Law and the } \\
\text { Criminal Code. The Labour Law applies to both private and public employees, and addresses moral harassment, } \\
\text { discrimination, and professional equality between men and women. The Criminal Code imposes a criminal } \\
\text { sanction for bullying. }\end{array}$ \\
\hline Ireland & $\begin{array}{l}\text { Nobody would be excluded from Irish nationality and citizenship due to gender. The age of eighteen and are } \\
\text { not regarded as noncompetent by the law and comply with the provisions of law regulating the election of the } \\
\text { members of the House of Representatives have the right to vote in the elections of the members of the House } \\
\text { of Representatives. }\end{array}$ \\
\hline Spain & $\begin{array}{l}\text { The Spanish are equal before the law and can in no way be discriminated due to birth, race, gender, religion, } \\
\text { opinion or any personal, social conditions or situations. }\end{array}$ \\
\hline Sweden & $\begin{array}{l}\text { No law or provision may include a negative treatment to anybody due to ethnical origin, colour or a concern } \\
\text { with minority group because of other conditions or sexual orientation. Sweden is the first country which has } \\
\text { made special legislative regulations against mobbing. }\end{array}$ \\
\hline Norway & $\begin{array}{l}\text { Norway, which follows a similar way with Finland, is of interest for several reasons. First, the Norwegian Work } \\
\text { Environment Act makes it explicit that it is the employer's responsibility to protect employees against exposure } \\
\text { to adverse physical and mental strain'. Second, it implicitly grades possible offences by highlighting various } \\
\text { forms of adverse effects including 'improper conduct', 'breach of employees' dignity and respect' and } \\
\text { 'harassment'. Third, the dynamic aspects of the law are emphasized that 'standards shall be continuously } \\
\text { developed and improved in accordance with developments in society'. }\end{array}$ \\
\hline Italy & $\begin{array}{l}\text { All the citizens are equal before the law and socially equal without any discrimination in terms of gender, race, } \\
\text { language, religion, political view, personal and social conditions. There is no specific legislation related with } \\
\text { mobbing or other forms of harassment. But a body of case law has been developed to clearly establish a } \\
\text { definition for an unacceptable behaviour and present what steps an employer should take both to prevent } \\
\text { such conduct and deal with problems when they occur. }\end{array}$ \\
\hline Poland & $\begin{array}{l}\text { Mobbing was firstly regulated legally in Poland with the amendment in law which was implemented on } 1 \text { st } \\
\text { January, 2004. In accordance with the 1st paragraph of 94th article of Polish Labour Law, employers are } \\
\text { responsible for preventing mobbing. }\end{array}$ \\
\hline Romania & $\begin{array}{l}\text { Romania is the common and inseperable homeland of all citizens without any discrimination in terms of race, } \\
\text { nationality, ethnical origin, language, religion, gender, opinion, political commitment, property and social } \\
\text { origin. }\end{array}$ \\
\hline Turkey & $\begin{array}{l}\text { Everybody is equal before the law without any discrimination due to the reasons such as language, race, colour, } \\
\text { gender, policial view, philosophical belief, religion, sect and so on. }\end{array}$ \\
\hline
\end{tabular}

\section{GENDER DISCRIMINATION AND MOBBING IN EUROPEAN UNION COUNTRIES AND TURKEY}

Table 3 indicates the rank of EU countries which did not perform gender discrimination in general, economical, educational and political contexts covering the years of 2008-2018 as the data of the Global Gender Report. According to the table 3, Sweden, Ireland, France and Denmark were the countries with the lowest levels in gender discrimination in all years in general meaning. 
Table 3: The Global Gender Report

\begin{tabular}{|c|c|c|c|c|c|c|c|c|c|c|c|c|c|c|c|c|c|c|c|c|c|c|c|c|}
\hline & \multicolumn{4}{|c|}{2018} & \multicolumn{4}{|c|}{2017} & \multicolumn{4}{|c|}{2016} & \multicolumn{4}{|c|}{2015} & \multicolumn{4}{|c|}{2014} & \multicolumn{4}{|c|}{2013} \\
\hline & $\begin{array}{l}\overline{\widetilde{J}} \\
\bar{\Xi} \\
\bar{\Xi} \\
\end{array}$ & 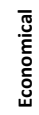 & 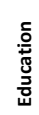 & 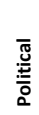 & 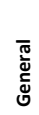 & 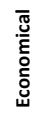 & 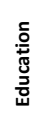 & 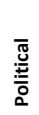 & 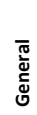 & 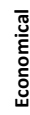 & 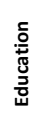 & 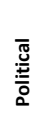 & 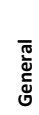 & 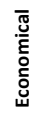 & 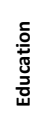 & 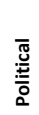 & 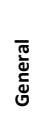 & 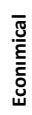 & 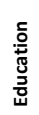 & 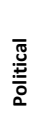 & 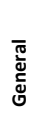 & 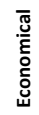 & 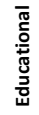 & 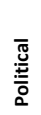 \\
\hline Sweden & 3 & 9 & 52 & 7 & 5 & 12 & 37 & 8 & 4 & 11 & 36 & 6 & 4 & 4 & 54 & 5 & 4 & 15 & 43 & 5 & 4 & 14 & 38 & 4 \\
\hline Ireland & 9 & 43 & 57 & 8 & 8 & 50 & 1 & 6 & 6 & 49 & 1 & 5 & 5 & 26 & 44 & 6 & 8 & 28 & 40 & 8 & 6 & 29 & 37 & 6 \\
\hline France & 12 & 63 & 1 & 10 & 11 & 64 & 1 & 9 & 17 & 64 & 1 & 19 & 15 & 56 & 1 & 19 & 16 & 57 & 1 & 20 & 45 & 67 & 1 & 45 \\
\hline Denmark & 13 & 38 & 1 & 15 & 14 & 36 & 1 & 16 & 19 & 34 & 1 & 29 & 14 & 20 & 1 & 29 & 5 & 12 & 1 & 7 & 8 & 25 & 1 & 45 \\
\hline Germany & 14 & 36 & 97 & 12 & 12 & 43 & 96 & 10 & 13 & 57 & $\begin{array}{l}10 \\
0 \\
\end{array}$ & 10 & 11 & 38 & 88 & 11 & 12 & 34 & 34 & 11 & 14 & 46 & 86 & 15 \\
\hline UK & 15 & 52 & 38 & 21 & 15 & 53 & 36 & 17 & 20 & 53 & 34 & 24 & 18 & 43 & 37 & 23 & 26 & 46 & 32 & 33 & 18 & 35 & 31 & 29 \\
\hline Holland & 27 & 56 & 1 & 28 & 32 & 82 & 1 & 25 & 16 & 76 & 60 & 14 & 13 & 39 & 1 & 13 & 14 & 51 & 1 & 9 & 13 & 26 & 44 & 22 \\
\hline Spain & 29 & 80 & 47 & 24 & 24 & 81 & 45 & 22 & 29 & 72 & 43 & 26 & 25 & 67 & 47 & 26 & 29 & 84 & 87 & 23 & 30 & 76 & 40 & 27 \\
\hline Belgium & 32 & 49 & 34 & 39 & 31 & 46 & 1 & 37 & 24 & 37 & 1 & 35 & 19 & 34 & 1 & 35 & 10 & 27 & 73 & 13 & 11 & 34 & 67 & 14 \\
\hline Portugal & 37 & 44 & 82 & 46 & 33 & 35 & 70 & 43 & 31 & 46 & 63 & 36 & 39 & 46 & 60 & 41 & 39 & 44 & 68 & 44 & 51 & 66 & 56 & 46 \\
\hline Poland & 42 & 51 & 50 & 50 & 29 & 55 & 31 & 49 & 38 & 58 & 31 & 44 & 51 & 75 & 38 & 52 & 57 & 61 & 36 & 68 & 54 & 73 & 37 & 49 \\
\hline Italy & 70 & $\begin{array}{l}11 \\
8 \\
\end{array}$ & 61 & 38 & 82 & $\begin{array}{l}11 \\
8 \\
\end{array}$ & 60 & 46 & 50 & $\begin{array}{l}11 \\
7 \\
\end{array}$ & 56 & 25 & 41 & $\begin{array}{l}11 \\
1 \\
\end{array}$ & 58 & 24 & 69 & $\begin{array}{l}11 \\
4 \\
\end{array}$ & 62 & 37 & 71 & 97 & 65 & 44 \\
\hline Turkey & $\begin{array}{l}13 \\
0 \\
\end{array}$ & $\begin{array}{l}13 \\
1\end{array}$ & $\begin{array}{l}10 \\
6 \\
\end{array}$ & $\begin{array}{l}11 \\
3 \\
\end{array}$ & $\begin{array}{l}13 \\
1 \\
\end{array}$ & $\begin{array}{l}12 \\
8\end{array}$ & $\begin{array}{l}10 \\
1 \\
\end{array}$ & $\begin{array}{l}11 \\
8\end{array}$ & $\begin{array}{l}13 \\
0\end{array}$ & $\begin{array}{l}12 \\
9 \\
\end{array}$ & $\begin{array}{l}10 \\
9\end{array}$ & $\begin{array}{l}11 \\
3\end{array}$ & $\begin{array}{l}13 \\
0\end{array}$ & $\begin{array}{l}13 \\
1\end{array}$ & $\begin{array}{l}10 \\
5 \\
\end{array}$ & $\begin{array}{l}10 \\
5 \\
\end{array}$ & $\begin{array}{l}12 \\
5 \\
\end{array}$ & $\begin{array}{l}13 \\
2 \\
\end{array}$ & $\begin{array}{l}10 \\
5 \\
\end{array}$ & $\begin{array}{l}11 \\
3 \\
\end{array}$ & $\begin{array}{l}12 \\
0\end{array}$ & $\begin{array}{l}12 \\
7\end{array}$ & $\begin{array}{l}10 \\
4\end{array}$ & $\begin{array}{l}10 \\
3 \\
\end{array}$ \\
\hline & \multicolumn{4}{|c|}{2012} & \multicolumn{4}{|c|}{2011} & \multicolumn{4}{|c|}{2010} & \multicolumn{4}{|c|}{2009} & \multicolumn{4}{|c|}{2008} & & & & \\
\hline Sweden & 4 & 10 & 39 & 4 & 4 & 7 & 41 & 4 & 4 & 11 & 41 & 4 & 4 & 6 & 39 & 4 & 3 & 5 & 33 & 4 & & & & \\
\hline Ireland & 5 & 29 & 30 & 6 & 5 & 30 & 1 & 6 & 6 & 25 & 1 & 7 & 8 & 43 & 1 & 8 & 8 & 48 & 1 & 8 & & & & \\
\hline France & 57 & 62 & 1 & 63 & 48 & 61 & 1 & 46 & 46 & 60 & 1 & 47 & 18 & 61 & 1 & 9 & 15 & 53 & 1 & 18 & & & & \\
\hline Denmark & 7 & 16 & 1 & 11 & 7 & 13 & 1 & 10 & 7 & 23 & 1 & 10 & 7 & 20 & 1 & 11 & 7 & 28 & 1 & 10 & & & & \\
\hline Germany & 13 & 31 & 83 & 15 & 11 & 32 & 50 & 15 & 13 & 37 & 51 & 15 & 12 & 37 & 49 & 13 & 11 & 45 & 49 & 16 & & & & \\
\hline UK & 18 & 33 & 27 & 29 & 16 & 33 & 1 & 23 & 15 & 34 & 1 & 22 & 15 & 35 & 1 & 22 & 13 & 42 & 1 & 21 & & & & \\
\hline Holland & 11 & 24 & 1 & 16 & 15 & 27 & 32 & 26 & 17 & 31 & 39 & 25 & 11 & 49 & 51 & 10 & 9 & 51 & 59 & 12 & & & & \\
\hline Spain & 26 & 75 & 38 & 27 & 12 & 74 & 37 & 5 & 11 & 78 & 40 & 5 & 17 & 90 & 56 & 9 & 17 & 89 & 58 & 7 & & & & \\
\hline Belgium & 12 & 36 & 67 & 10 & 13 & 36 & 63 & 17 & 14 & 39 & 62 & 16 & 33 & 64 & 71 & 29 & 28 & 60 & 67 & 27 & & & & \\
\hline Portugal & 47 & 55 & 57 & 43 & 35 & 59 & 55 & 34 & 32 & 56 & 69 & 32 & 46 & 53 & 76 & 47 & 39 & 39 & 71 & 45 & & & & \\
\hline Poland & 53 & 72 & 34 & 46 & 42 & 65 & 28 & 40 & 43 & 63 & 29 & 87 & 50 & 71 & 33 & 40 & 49 & 73 & 30 & 39 & & & & \\
\hline Italy & 80 & $\begin{array}{l}10 \\
1\end{array}$ & 65 & 71 & 74 & 90 & 48 & 55 & 74 & 97 & 49 & 54 & 72 & 95 & 46 & 45 & 67 & 85 & 43 & 46 & & & & \\
\hline Turkey & $\begin{array}{l}12 \\
4\end{array}$ & $\begin{array}{l}12 \\
9\end{array}$ & $\begin{array}{l}10 \\
8\end{array}$ & 98 & $\begin{array}{l}12 \\
2 \\
\end{array}$ & $\begin{array}{l}13 \\
2 \\
\end{array}$ & $\begin{array}{l}10 \\
6 \\
\end{array}$ & 89 & $\begin{array}{l}12 \\
6 \\
\end{array}$ & $\begin{array}{l}13 \\
1 \\
\end{array}$ & $\begin{array}{l}10 \\
9 \\
\end{array}$ & 99 & $\begin{array}{l}12 \\
9 \\
\end{array}$ & $\begin{array}{l}13 \\
0 \\
\end{array}$ & $\begin{array}{l}11 \\
0 \\
\end{array}$ & $\begin{array}{l}10 \\
7 \\
\end{array}$ & $\begin{array}{l}12 \\
3 \\
\end{array}$ & $\begin{array}{l}12 \\
4 \\
\end{array}$ & $\begin{array}{l}10 \\
8 \\
\end{array}$ & $\begin{array}{l}10 \\
6 \\
\end{array}$ & & & & \\
\hline
\end{tabular}

\section{Methodology}

\subsection{Model and Hypotheses of the Study}

Model of the study was established based on the variables in studies as a result of the literature review. As a result of the literature review, the model and hypotheses established in accordance with the purpose of the study are indicated as follows. 
Figure 1: Model of the Study
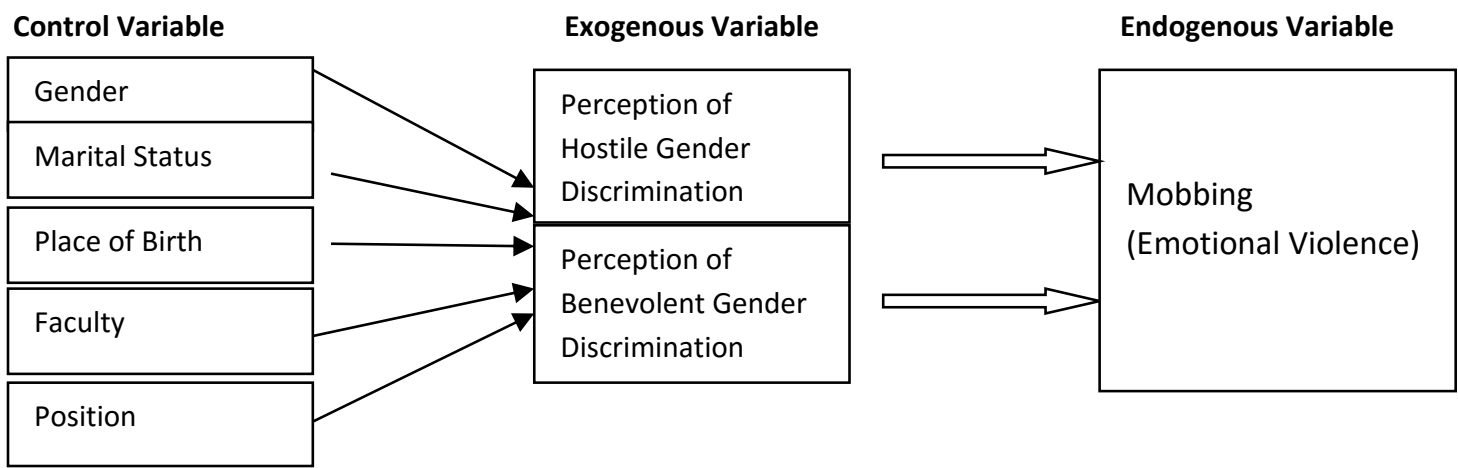

Hypothesis 1: Perception of hostile gender discrimination affects the incidence of mobbing positively

Hypothesis 2: Perception of benevolent gender discrimination affects the incidence of mobbing positively.

Hypothesis 3: Perception of gender discrimination in the incidence of mobbing varies according to gender.

Hypothesis 4: Perception of gender discrimination in the incidence of mobbing varies according to marital status.

Hypothesis 5: Perception of gender discrimination in the incidence of mobbing varies according to the place of birth.

Hypothesis 6: Perception of gender discrimination in the incidence of mobbing varies according to the faculty that academicians work for.

Hypothesis 7: Perception of gender discrimination in the incidence of mobbing varies according to position.

\subsection{Variables of the Study}

Glick, P., and Fiske, S.T.'s (1996) study was adapted in order to measure gender discrimination in the study. The second survey was about mobbing and it was obtained from Leymann, H.'s (1990) study. Gender discrimination scale consists of 22 statements and it has two dimensions as the perception of hostile gender discrimination and the perception of benevolent gender discrimination. The original form of mobbing scale consists of 45 statements. However, the questions in the survey were adapted for academicians and the number of statements was reduced to 20 . A pilot study was conducted for the reliability of the scale and surveys began to be applied after the reliability level was measured.

The perception of hostile gender discrimination and the perception of benevolent gender discrimination were exogenous variables; however, mobbing was an endogenous variable in the study.

\subsection{Data Collection Method}

Surveys in the study were applied to the academic staff in Afyon Kocatepe University. A total of 400 survey papers were handed out and 285 available data were obtained. In the study the data including demographic properties were requested, but personal data were not.

The hypotheses of the study were tested through Structural Equation Model. The Structural Equation Model is basically a combination of factor analysis and regression analysis. It tests the convenience of the predicted covariance matrix established in accordance with the theoretical model with the observed covariance matrix (Hox and Bechger, 1995).

\subsection{Data Evaluation Technique}

Validity and reliability tests were performed in order to obtain the structural validity of the scale. After the data were entered to SPSS 16.0 package programme, reliability analysis and exploratory factor analysis were performed in SPSS programme and Structural Equation Modelling was performed in AMOS 19 programme to determine the effects of data on each other. 


\subsection{Testing the Scales in the Study}

In order to test the validity of the used scales, by using AMOS19 programme single factoral confirmatory factor analysis was made for the perception of gender discrimination and mobbing scale. Since the fit values generated by scaling models created for testing the validity of scales was not at acceptable ranges, and the modifications recommended by the programme were made. The changes in scales as a result of modifications are indicated in Table 4 and the fit values generated by scaling models are indicated in Table 5.

Table 4: Changes in the Scales

\begin{tabular}{|l|l|c|c|}
\hline \multicolumn{2}{|c|}{ Scales } & Number of Statements & Number of Extracted Statements \\
\hline $\begin{array}{l}\text { Perception of Gender } \\
\text { Discrimination Scale }\end{array}$ & Hostile & 11 & 1 \\
\cline { 2 - 4 } & Benevolent & 11 & 2 \\
\hline Mobbing Scale & 20 & 6 \\
\hline
\end{tabular}

As can be seen in Table 4, the numbers of statements exracted from the scales are as follows; 1 statement from the perception of hostile gender discrimination scale, 2 statements from the perception of benevolent gender discrimination scale, and 6 statements from the mobbing scale.

Table 5: Fit Values of the Scales

\begin{tabular}{|c|c|c|c|c|c|c|c|}
\hline & & $x 2$ & df & $x 2 / d f$ & GFI & CFI & RMSEA \\
\hline \multirow{2}{*}{$\begin{array}{l}\text { Perception of } \\
\text { Gender } \\
\text { Discrimination } \\
\text { Scale }\end{array}$} & $\begin{array}{l}\text { Perception of Hostile } \\
\text { Gender Discrimination }\end{array}$ & 64,437 & 34 & 1,89 & 0,96 & 0,97 & 0,05 \\
\hline & $\begin{array}{l}\text { Perception of } \\
\text { Benevolent Gender } \\
\text { Discrimination }\end{array}$ & 75,112 & 25 & 3,00 & 0,94 & 0,93 & 0,08 \\
\hline \multicolumn{2}{|l|}{ Mobbing Scale } & 219,80 & 72 & 3,05 & 0,90 & 0,95 & 0,085 \\
\hline \multicolumn{2}{|c|}{ Goodness of Fit Values } & & & $\leq 3$ & $\geq 90$ & $\geq 0,97$ & $\leq 0,05$ \\
\hline \multicolumn{2}{|c|}{ Acceptable Fit Values } & & & $\leq 5$ & $0,89-0,85$ & $\geq 95$ & $0,06-0,08$ \\
\hline
\end{tabular}

p>.05, $x 2$ =Chi-Square; df= Degree of Freedom; GFI= Goodness of Fit Index; CFI= Comparative Fit Index;

RMSEA = Root Mean Square Error of Approximation

Resource: Meydan and Şeşen, 2015: 37.

$\mathrm{x} 2$ tests the significance of the difference between the observed covariance matrix and the predicted covariance matrix. It is affected by sample size. Therefore, the larger the sample, the more significant $\times 2$ values will be. For that reason, it is suggested that the value obtained by dividing $\times 2$ value by the degree of freedom is taken as the basis when evaluating the model fit. Root Mean Square Error of Approximation (RMSEA) is the square root of the average of the prediction errors. RMSEA is a statistics that provides information about the compatibility of the unknown but optimally planned parameters with the covariance matrix of the main mass. GFI (Goodness of Fit Index) was created to eliminate the problem of increasing the chi-square statistics as the sample grows and is less sensitive to the sample size. The GFI statistic is between 0 and 1 and moves inversely proportional to the degree of freedom; therefore, it can be said that the ratio of sample size to degree of freedom tends to increase as it increases. CFI (Comparative Fit Index) is an improved version of the NFI statistic, which also takes into account the sample size and gives good results even in small samples, one of the most accepted and used statistics. NFI likewise results in a comparison of the zero models with the sample covariance matrix and takes a value between 0 and 1. Approaching 1 increases the suitability of the model (Yaşlıoğlu, 2017: 80-81) (Meydan and Şeşen, 2015: 32-35).

\subsection{Findings}

Cronbach Alpha and KMO values of the data obtained from the surveys of the study are given below. 
Table 6: Cronbach Alpha Coefficient of the Scales

\begin{tabular}{|l|c|}
\hline & Cronbach Alpha \\
\hline Perception of Gender Discrimination Scale &, 88 \\
\hline Mobbing Scale &, 97 \\
\hline
\end{tabular}

As Table 6 is analyzed, we can see that reliability of both Perception of Gender Discrimination Scale and Mobbing Scale are high.

$>$ If $0,00 \leq \alpha<0,40$, the scale is not reliable,

$>$ If $0,40 \leq \alpha<0,60$, reliability of the scale is low,

$>$ If $0,60 \leq \alpha<0,80$, the scale is highly reliable,

$>$ If $0,80 \leq \alpha<1,0$, the scale is highly reliable.

Table 7: KMO Value of the Scale

\begin{tabular}{|l|l|c|}
\hline \multicolumn{3}{|c|}{ KMO and Bartlett's Test } \\
\hline Kaiser-Meyer-Olkin Measure of Sampling Adequacy. &, 910 \\
\hline Bartlett's Test of Sphericity & Approx. Chi-Square & 11806,611 \\
\cline { 2 - 3 } & Df & 1431 \\
\cline { 2 - 3 } & Sig. &, 000 \\
\hline
\end{tabular}

When the criteria are analyzed, result of KMO value of the study is excellent

KMO: $1,00 \leq K M O 0,90=$ Excellent

KMO: $0,90 \leq K M O 0,80=$ Good

KMO: $0,80 \leq K M O 0,70=$ Medium

KMO: $0,70 \leq K M O 0,60=$ Poor

$K M O: 0,60 \leq K M O=B a d$

Table 8: Demographic Properties of Participants

\begin{tabular}{|l|l|c|c|}
\hline \multirow{4}{*}{ Gender } & & Frequency & Percentage \% \\
\hline \multirow{4}{*}{ Marital Status } & Male & 186 & 65,3 \\
\cline { 2 - 4 } & Female & 99 & 34,7 \\
\cline { 2 - 4 } & Sarried & 203 & 71,2 \\
\hline \multirow{5}{*}{ Title } & Village & 82 & 28,8 \\
\cline { 2 - 4 } & Town/District & 11 & 3,9 \\
\cline { 2 - 4 } & County & 7 & 2,5 \\
\cline { 2 - 4 } & Province & 56 & 19,6 \\
\cline { 2 - 4 } & Metropolitan & 134 & 47,0 \\
\cline { 2 - 4 } & Research Assistant & 77 & 27,0 \\
\cline { 2 - 4 } & Lecturer & 96 & 33,7 \\
\cline { 2 - 4 } & Asst.Prof. & 53 & 18,6 \\
\cline { 2 - 4 } & Assoc.Prof & 34 & 24,2 \\
\cline { 2 - 4 } & Prof.Dr. & 33 & 11,9 \\
\hline Faculty & School of Economics and Administrative Sciences & 43 & 11,6 \\
\cline { 2 - 4 } & Eduation And Technology & 38 & 13,1 \\
\cline { 2 - 4 } & Science And Letters & 65 & 22,8 \\
\cline { 2 - 4 } & Law & 11 & 3,9 \\
\hline
\end{tabular}




\begin{tabular}{|l|l|c|c|}
\hline \multirow{2}{*}{} & Veterinary & 24 & 8,4 \\
\cline { 2 - 4 } & Fine Arts & 27 & 9,5 \\
\cline { 2 - 4 } & Tourism & 16 & 5,6 \\
\cline { 2 - 4 } & Theology & 2 &, 7 \\
\cline { 2 - 4 } & Engineering & 43 & 15,1 \\
\cline { 2 - 4 } & Vocational High School & 8 & 1,8 \\
\cline { 2 - 4 } & Foreign Languages & 3 & 2,8 \\
\cline { 2 - 4 } & Physical Education and Sports & 8,1 \\
\hline
\end{tabular}

According to the Table $8,65,3 \%$ of the participants are male and $34,7 \%$ of them are female, $71,2 \%$ are married and $28,8 \%$ are single. In this grup, 3,8 \% of the participants were born in villages, $2,5 \%$ were born in towns/districts, $19,6 \%$ were born in counties, $47,0 \%$ were born in provinces and $27,0 \%$ of the participants were born in metropolitans. When title is considered, we can see that $33,7 \%$ of the academicians are Research Assistants, $18,6 \%$ are Lectures, $24,2 \%$ are Dr. Lecturers, $11,9 \%$ are Associate Professors and $11,6 \%$ is Professors. In terms of faculty status, $15,1 \%$ of the participants in School of Economics and Administrative Sciences._13,3\% in Education and Technology, 22,8\% in Science and Letters, 3,9\% in Law, 8,4\% in Veterinary, $9,5 \%$ in Fine Arts. 5,6\% in Tourism, 0,7\% in Theology, 15,1\% in Engineering, 1,8\% in Vocational High School. 1,8\% in Foreign Language and 1,1\% in Physical Education and Sports.

\subsection{Structural Equation Model}

Since the fit values of the model in Figure 2 were not at acceptable ranges, the numbers of statements exracted from the scales are as follows; 1 statement from the hostile gender discrimination scale, 1 statement from the benevolent gender discrimination scale, and 1 statement from the mobbing scale.

Figure 2: Structural Equation Model

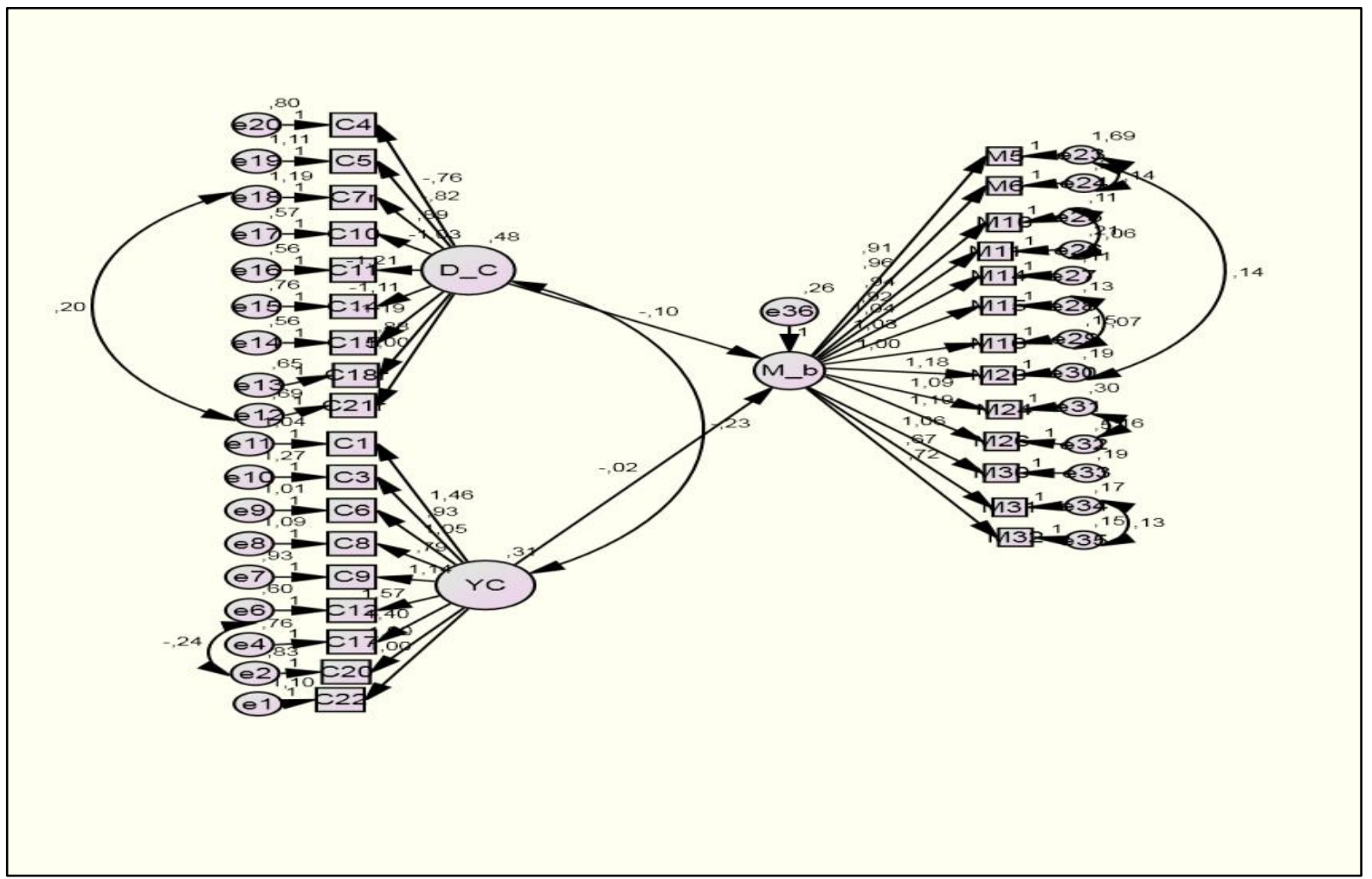


As a result of the conducted modification, it was observed that fit values of the model were within the good fit value ranges and sufficient proofs indicating that model were structurally suitable were obtained. Fit values of the model are indicated in Table 9.

\section{Table 9: Fit Values of Structural Equation}

\begin{tabular}{|l|l|l|l|l|l|l|}
\hline & \multicolumn{1}{|c|}{$\mathbf{x}^{\mathbf{2}}$} & $\mathbf{d f}$ & $\mathbf{x}^{\mathbf{2}} / \mathbf{d f}$ & $\mathbf{G F I}$ & CFI & RMSEA \\
\hline Before the statements were extracted & 1025,411 & 520 & 1,97 & 0,82 & 0,89 & 0,06 \\
\hline After the statements were extracted & 740,828 & 424 & 1,74 & 0,86 & 0,93 & 0,05 \\
\hline Goodness Fit Values & & & $\leq 3$ & $\geq 90$ & $\geq 0,97$ & $\leq 0,05$ \\
\hline Acceptable Fit Values & & & $\leq 5$ & $0,89-0,85$ & $\geq 95$ & $0,06-0,08$ \\
\hline
\end{tabular}

$\beta$ coefficients, standard error, $p$ and $x^{2}$ values between variables according to the established model are indicated in Table 10.

Table 10: $\beta$ Coefficients, Standard Error, $p$ and $x^{2}$ Values between Variables

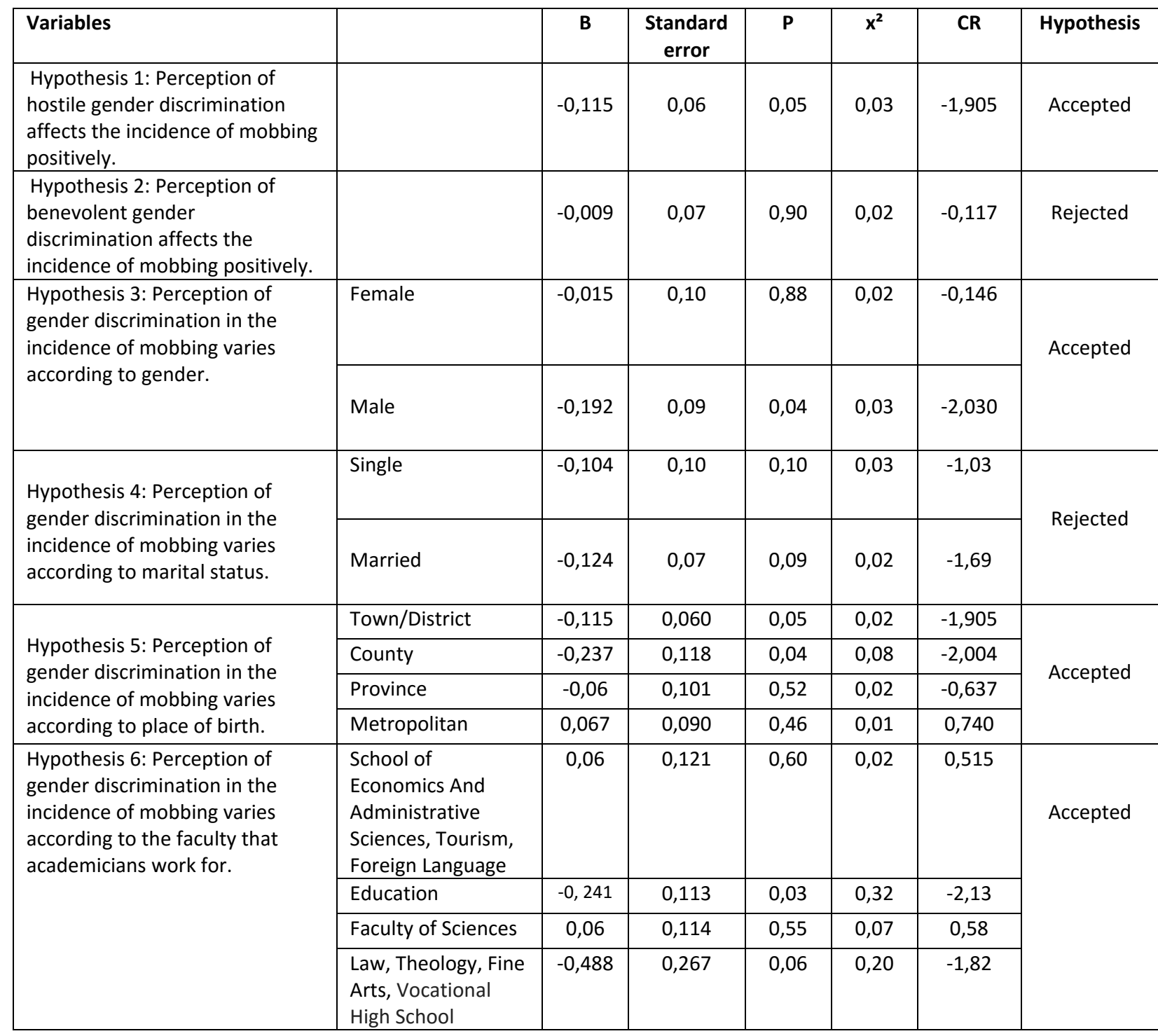




\begin{tabular}{|l|l|c|c|c|c|c|c|}
\hline & $\begin{array}{l}\text { Veterinary, } \\
\text { Engineering }\end{array}$ & $-0,238$ & 0,149 & 0,05 & 0,07 & $-1,92$ & \\
\hline \multirow{3}{*}{$\begin{array}{l}\text { Hypothesis 7: Perception of } \\
\text { gender discrimination in the } \\
\text { incidence of mobbing varies } \\
\text { according to position. }\end{array}$} & Research Asst. & 0,100 & 0,090 & 0,265 & 0,05 & 1,115 & \\
\cline { 2 - 8 } & Lecturers & $-0,250$ & 0,139 & 0,07 & 0,08 & $-1,795$ & Accepted \\
\cline { 2 - 8 } & Asst. Prof. & $-0,08$ & 0,119 & 0,45 & 0,02 & $-0,753$ & $-1,94$ \\
\cline { 2 - 8 } & $\begin{array}{l}\text { Assoc. Prof. and } \\
\text { Prof. }\end{array}$ & 0,332 & 0,170 & 0,05 & 0,10 & - \\
\hline
\end{tabular}

When the obtained values are analyzed,

Hypothesis 1. Perception of hostile gender discrimination affects the incidence of mobbing positively. Since the value is $p<0,05$ in the relationship between the perception of hostile gender discrimination and mobbing, there is a significant relationship and the hypothesis is accepted.

Hypothesis 2. Perception of benevolent gender discrimination affects the incidence of mobbing positively. Since the value of $p<0,05$ is not obtained in the relationship between the perception of benevolent gender discrimination and the value is $p=0,90$, the hypothesis is rejected.

Hypothesis 3. In the hypothesis of the perception of gender discrimination, in the incidence of mobbing varies according to gender, the value is $p=0,88$ for females and it is $p<0,04$ for males. So, it means that the perception of gender discrimination of females and males in the incidence of mobbing makes a difference; therefore the hypothesis is accepted.

Hypothesis 4. In the hypothesis of the perception of gender discrimination in the incidence of mobbing varies according to marital status the values are $p=0,09$ for single academicians and $p=0,10$ for married ones. It means that the perception of gender discrimination of single and married academicians in the incidence of mobbing makes no significant difference, therefore the hypothesis is rejected.

Hypothesis 5. In the hypothesis of the perception of gender discrimination, in the incidence of mobbing varies according to the place of birth the values are $p=0,05$ for town/district, $p=0,04$ for county, $p=0,52$ for province and $p=0,46$ for metropolitans. $p$ values of the academicians grown in towns/districts and counties are $p<0,05$. In other words, the perception of gender discrimination of the academicians grown in towns/districts and counties is high. Therefore the hypothesis is accepted.

Hypothesis 6 . The perception of gender discrimination in the incidence of mobbing varies according to the faculty that academicians work for. The value is $p=0,60$ for School of Economics And Administrative Sciences, Tourism, Foreign Languages and Faculty of Sciences. The value is $p=0,03$ in Faculty of Education, $p=0,55$ in Faculty of Science, $p=0,06$ in Faculty of Law, Theology, Fine Arts and Vocational High School, and $p=0,05$ in Faculty of Veterinary and Engineering. When we look at $p$ value among the faculties, we can see that tshe perception of gender discrimination in the incidence of makes significant diference. $p=0.03$ in the Faculty of Education and $p=0.05$ in the Faculty of Veterinary and Engineering. Therefore, it shows that the perception of gender discrimination affects the formation of mobbing. But the other faculties $p$ values are not obtained $p<$ 0,05 values. Therefore the hypothesis is accepted.

Hypothesis 7. The perception of gender discrimination in the incidence of mobbing varies according to title. The obtained values are $p=0,26$ in research assistants, $p=0,07$ for lecturers, $p=0,45$ for Assistant Professors, $p=0,05$ for Associate Professors and Professors. The value of $p<0,05$ is obtained for Associate Professors and Professors. Therefore the hypothesis is accepted.

\section{CONCLUSION AND RECOMMENDATIONS}

As well as discrimination is a social problem, we can see that the laws and regulations legitimizing the discrimination and also culture of the society have an important role in the incidence of gender discrimination. Supporting the search of equality is a prerequisite in social and cultural sense besides the legislative amendments and regulations. Otherwise, secondary position of women in society will continue as being exposed to exploitation, exclusion and oppression through their genders.

In this study, in which we aimed to present the perception of gender discrimination preventing the promotion of women employees to administritive positions in business life. They deserve and determine the effect of that perception on the incidence of mobbing it was observed that women employees exposed to many discriminations besides gender 
discrimination. This study has indicated that individuals in the society and the cultural values of these individuals have a great effect on gender discrimination. It has been determined that this effect triggers the incidence of mobbing.

The results of the hypothesis are as follows:

Perception of hostile gender discrimination affects the incidence of mobbing positively. Since the value is $p<0,05$ in the relationship between the perception of hostile gender discrimination and mobbing, there is a significant relationship and the hypothesis is accepted. Perception of benevolent gender discrimination affects the incidence of mobbing positively. Since the value of $p<0,05$ is not obtained in the relationship between the perception of benevolent gender discrimination and the value is $p=0,90$, the hypothesis is rejected. In the hypothesis of the perception of gender discrimination, in the incidence of mobbing varies according to gender, the value is $p=0,88$ for females and it is $p<0,04$ for males. So, it means that the perception of gender discrimination of females and males in the incidence of mobbing makes a difference; therefore the hypothesis is accepted. In the hypothesis of the perception of gender discrimination in the incidence of mobbing varies according to marital status the values are $p=0,09$ for single academicians and $p=0,10$ for married ones. It means that the perception of gender discrimination of single and married academicians in the incidence of mobbing makes no significant difference, therefore the hypothesis is rejected. In the hypothesis of the perception of gender discrimination, in the incidence of mobbing varies according to the place of birth the values are $p=0,05$ for town/district, $p=0,04$ for county, $p=0,52$ for province and $p=0,46$ for metropolitans. $p$ values of the academicians grown in towns/districts and counties are $p<0,05$. In other words, the perception of gender discrimination of the academicians grown in towns/districts and counties is high. Therefore the hypothesis is accepted. The perception of gender discrimination in the incidence of mobbing varies according to the faculty that academicians work for. The value is $p=0,03$ in Faculty of Education, $p=0,55$ in Faculty of Science, $p=0,06$ in Faculty of Law, Theology, Fine Arts and Vocational High School, and $p=0,05$ in Faculty of Veterinary and Engineering. When we look at $p$ value among the faculties, we can see that tshe perception of gender discrimination in the incidence of makes significant diference. $p=0.03$ in the Faculty of Education and $p=0.05$ in the Faculty of Veterinary and Engineering. When we look at $p$ value among the faculties, we can see that the perception of gender discrimination in the incidence of makes significant diference. When the $p$ values were examined, a significant difference was found between gender discrimination and mobbing in Education, Veterinary and Engineering faculties. In other faculties, there is no difference. Therefore the hypothesis is accepted. The perception of gender discrimination in the incidence of mobbing varies according to title. The obtained values are $p=0,26$ in research assistants, $p=0,07$ for lecturers, $p=0,45$ for Assistant Professors, $p=0,05$ for Associate Professors and Professors. The value of $p<0,05$ is obtained for Associate Professors and Professors. Therefore the hypothesis is accepted.

When the results of the hypotheses are analyzed, it can be seen that the perception of social gender is an important factor for the incidence of mobbing. It has been determined that the demographic factors such as gender, place of birth, marital status, the faculty that academicians work for and title affect the attitudes about discrimination and lead to the incidence of mobbing. The hypothesis that marital status leads to the incidence of mobbing affecting the attitutes about gender discrimination has been rejected.

The incidence of mobbing creates negative individual, social and organizational consequences. It is important to eliminate these negative consequences. While individual consequences affect the mental health and life quality of an individual, social effects of mobbing are more serious. It has been determined that mobbing has a performance decreasing effect for a business in terms of organizational aspect. In this concept mobbing is a phenomenon that measures should be taken for eliminate. It can be seen in the literature that the mobbers are usually males and this triggers the incidence of gender discriminationbased mobbing. It has also been identified in our study that the perception of gender discrimination is important in the incidence of mobbing. For that reason, studies to decrease the perception of gender discrimination in society should be conducted in order to prevent the incidence of mobbing. The most important step to take for EU countries and Turkey about mobbing is to legislate in this field. Legal practices and sanctions to prevent mobbing should be implemented. It is also important to create awareness in the society in this issue. This awareness should be supported by mass media to enchance the awareness. 


\section{REFERENCES}

Aşkın, E.Ö., Aşkın, U., (2018), Çalışma Yaşamında Kadına Yönelik Mobbing: Bankacılık Sektöründe Bir Araştırma, Gümüşhane Üniversitesi Sosyal Bilimler Enstitüsü Elektronik Dergisi Cilt: 9, Sayı: 24.

Baillien, E., Griep, Y., Elst, T.V. And Witte, H. (2018), The Relationship Between Organisational Change And Being A Perpetrator Of Workplace Bullying: A Three-Wave Longitudinal Study, Work \& Stress, Https://Doi.Org/10.1080/02678373.2018.1496161.

Bingöl, O.(2014), "Toplumsal Cinsiyet Olgusu ve Türkiye'de Kadınlık”, KMÜ Sosyal ve Ekonomik Araştırmalar Dergisi 16 (Özel Sayı I): 108-114, ISSN: 2147 - 7833, www.kmu.edu.tr.

Buttigieg, D.M., Bryant, M., Hanley, J., Liu, J. (2011), The Causes And Consequences Of Workplace Bullyıng And Dıscrımınatıon: Results From An Exploratory Study, Labour And Industry 22:1/2 August/December, Pp. 117-142.

Carnero, M.A., Martinez, B., and Sanchez-Mangas, R. (2010), Mobbing and its determinants: the case of Spain, Applied Economics, 42, 37773787.

Çiftçi, M., (2010), AB-15 ülkelerinde kadın emeğinin gelir elastikiyeti ve Türkiye: değerlendirmeler-ekonometrik uygulamalar, Uluslararası Insan Bilimleri Dergisi [Bağlantıda]. 7:1. Erişim: http://www.insanbilimleri.com.

Çögenli, M.Z. and Döner E., (2015), Türkiye'de Akademisyenler Üzerine Gerçekleştirilen Mobbing Konulu Lisansüstü Çalışmaların İncelenmesi, Atatürk Üniversitesi Sosyal Bilimler Enstitüsü Dergisi, 19 (3): 27-46.

Çukur, C., (2016), Türk Hukuku ve Karşılaştırmalı Hukukta Iş̧yerinde Psikolojik Taciz, TBMM Basımevi, ekitap.

Davenport, N., Schwartz, R. D. Ve Ellıott, G. P. (2003), Mobbing İsyyerinde Duygusal Taciz, (Çev.) Osman Cem Önertoy, İstanbul: Sistem Yayıncilık.

Dragomır, O.M. (2018), A New Mılestone Of Human Resource Management- Mobbıng In A Contınuously Changıng Work Envıronment, Economics, Management, and Financial Markets 13(3), pp. 409-414, ISSN 1842-3191, elSSN 1938-212X.

Ergin, H., (2013), Avrupa Hukukunda Işsyerinde Psikolojik Taciz, 61-81, Çalışma Hayatında Psikolojik Taciz Panel ve Çalıştayı Bildiri Kitabı, Ankara.

Eroğlu, F., (2011), Avrupa Ülkeleri AnayasalarındaToplumsal Cinsiyet ve Kadın-Erkek Eşitliği ile Illgili Düzenlemeler, TBMM Araştırma Merkezi.

Escartin, J., Ullrich, J., Zapf, D., Schlüter, E., Dick, R., (2013), Individual- and group-level effects of social identification on workplace bullying, European Journal of Work and Organizational Psychology, Vol. 22, No. 2, 1 193, http://dx.doi.org/10.1080/1359432X.2011.647407

Glick, P., Fiske, S.T., (1996), The Ambivalent Sexism Inventory: Differentiating Hostile and Benevolent Sexism, Journal of Personality and Social Psychology, Vol. 70, No. 3, 491-512.

Gül, H., İnce, M. and Özcan, N. (2011), The Relationship between Workplace Mobbing and Burnout among Academics at a Turkish University, Research Journal of Internatıonal Studies - Issue 18.

Halaç, D.S. and Güloğlu, C., (2019), İşyerinde Psikolojik Yıldırma Olgusunun Çalışan Verimliliği Üzerine Etkisi: MOSB'de Bir Saha Araştırması, Yönetim ve Ekonomi: Celal Bayar Üniversitesi Iktisadi ve Idari Bilimler Fakültesi Dergisi, Cilt 26, Sayı 1, https://doi.org/10.18657/yonveek.321727.

Hox, J.J. ve T.M. Bechger (1995), “An Introduction to Structural Equation Modeling” Family Science Review, 11.

http://www.eurofound.europa.eu, (2007).

http://www.fedee.com/kb/italy-discrimination/ (01.08.2019).

http://www.ipsnews.net/2002/10/labour-rights-spain-fighting-bullying-in-the-workplace/ (01.08.2019).

https://www.schoenherr.eu/publications/publication-detail/poland-internal-employers-regulations/(01.08.2019).

Jenkins, M. F., Zapf, D., Winefield, H., Sarris, A., (2012), Bullying Allegations from the Accused Bully's Perspective, British Journal of Management, Vol. 23, 489-501, DOI: 10.1111/j.1467-8551.2011.00778.x.

Kara, D., Kim, H. L., and Uysal, M., (2018) The Effect of Manager Mobbing Behaviour on Female Employees'Quality of Life, Current Issues in Tourism, 21:13, 1453-1467, DOI: 10.1080/13683500.2015.1078298.

Kaya, R., (2015), İşçilerin Maruz Kaldığı Mobbing ve Ülkelerin Karşılaştırmalı Analizi, Akademik Sosyal Araştırmalar Dergisi, Yıl: 3, Sayı: 20, Aralık 2015, s. 369-381.

Kement, Ü., Batga, B., (2016), Mobbing'in Örgütsel Bağılıı̆a Etkisi: Eğlence ve İkram Amaçlı Hizmet Veren Rekreasyon İşletmelerinde Bir Araştırma, İşletme Araştırmaları Dergisi, DOI: 10.20491/isarder.2016.225. 
Khan, M. J., Kehkashan, A., Hafsah, A., Noreen, N., and Mehwash, N. (2018), Attitude of Male and Female University Students Towards Gender Discrimination, Pakistan Journal of Psychological Research, Vol. 33, No. 2, 429-436.

Konuk, B., (2014), Avrupa Birliği Hukukunda Cinsiyet Ayrımcılığına Illişkin Temel Kavramların Değerlendirilmesi, JOY, !725-1752.

Koonin, M. And Green T.M., (2007), The Emotionally Abusive Workplace, Journal of Emotional Ebuse, 4:3-4, 71-79, DOI: 10.1300/ J135v04n03 05 .

Kovacic, A., Podgornik, N., Pristov, Z., and Raspor, A., (2017), Mobbing in a Non-Profit Organization, Organizacija, Vol. 50, No.2, DOI: 10,1515/orga-2017-0012.

Leymann, H. (1990), Mobbing and Psychological Terror at Workplaces, Violence and Victims, Vol. 5, No. 2.

Leymann, H. (1996), "The Content And Development Of Mobbing At Work", European Journal Of Work And Organizational Psychology, Vol: 5, No:2, 165-184

McCormack, D., Djurkovic, N., Nsubuga-Kyobe, A., Casimir, G., (2018), Workplace Bullying, Employee Relations, Vol. 40 No. 2, pp. 264-280, DOI 10.1108/ER-07-2016-0147.

Meydan, C.H.\& Şeşen, H. (2015), Yapısal Eşitlik Modellemesi Amos Uygulamaları, Detay yayıncılık, Ankara.

Mulder, R., Bos, A.E.R., Pouwelse, M. And Dam, K. (2017), Workplace Mobbing: How the victim's coping behavior influences bystander responses, The Journal Of Social Psychology 2017, Vol. 157,No. 1, 16-29, Http://Dx.Doi.Org/10.1080/00224545.2016.1152213.

Nielsen, M.B. and Einarsen, S.V. (2018), what we know, what we do not know, and what we should and could have known about workplace bullying: An overview of the literature and agenda for future research, Aggression and Violent Behavior 42, 71-83, https://doi.org/10.1016/j.avb.2018.06.007.

Öztan, E., (2004), Toplumsal Cinsiyet Eşitliği Politikaları ve Olumlu Ayrımcılık, Ankara Üniversitesi SBF Dergisi, 59-1.

Policy Department for Citizens Rights' and Constitutional Affairs, (2018), http://www.europarl.europa.eu/RegData/etudes/STUD/2018/604949/IPOL STU(2018)604949 EN.pdf.

Poussard, J.M., Çelik, T.S. and Bingöl, H.B., (2018), Mobbing in Higher Education: Descriptive and Inductive Case Narrative Analyses of Mobber Behavior, Mobbee Responses, and Witness Support, Educational Sciences: Theory \& Practice, 18, $471-494$. http://dx.doi.org/10.12738/estp.2018.2.0018.

Salin, D. (2003), Ways of Expalning Workplace Bullying: A Review of Enabling, Motivating, and Precipitating Structures and Processes in the Work Environment, https://helda.helsinki.fi/bitstream/.../283/salin_HR_2003.pdf(01.08.2019).

Sarı, M., (2017), Türkiye'de Cinsiyete Dayalı Ayrımcılığın Kadının Çalışma ve Siyasal Yaşamdaki Yerine Etkisi, Insan ve Toplum Bilimleri Araştırmaları Dergisi, C.6, S.2.

Sarıçam, H., (2016), The Mediator Role of Social Safeness and Pleasure in Relation between Mobbing and Meaning of Work in Academicians, Education and Science, Vo. 41, No.184, 349-361, DOI. 10.15390/EB.2016,6201.

Sipe, S., Johnson, C.D., Fisher, D., (2009), University Students' Perseptions of Gender Discriination in the Workplace: Reality Versus Fiction, Journal of Education for Business, 339-349.

Sipe, S.R., Larson, L., McKay, B.A., Moss, J., (2016), Taking off the Blinders: A Comparative Study of University Students' Changing Perceptions of Gender Discrimination in the Workplace From 2006 to 2013, Academy of Management Learning \& Education, 2016, Vol. 15, No. 2, 232249. http://dx.doi.org/10.5465/amle.2014.0139.

Skewes, L., Fine, C., Haslam, N.(2018), Beyond Mars and Venus: The role of gender essentialism in support for gender inequality and backlash, Plos One, Https://Doi.Org/10.1371/Journal.Pone.0200921.

Snizek, W. E., \& Neil, C. C. (1992). Job characteristics, gender stereotypes and perceived gender discrimination in the workplace, Organization Studies, 13(3), 403-427, http://dx.doi.org/10.1177/017084069201300305.

Sobre-Denton, M.S. (2012), Stories From The Cage: Autoethnographic Sensemaking Of Workplace Bullying, Gender Discrimination, And White Privilege, Journal Of Contemporary Ethnography 41(2) 220-250, DoI: 10.1177/0891241611429301.

Stainback, K., Ratliff, T.N., Roscigno, V.J., (2011), the Context of Workplace Sex Discrimination: Sex Composition, Workplace Culture and Relative Power, Social Forças 891411166-1188.

Stefanovic, G.(2012), "Role of Trade Unions in the Prevention of Mobbing", SEER Journal for Labour and Social Affairs in Eastern Europe.

Şen, M., (2018), Cinsiyete Dayalı Ücret Eşitsizliğinin Avrupa Birliği ve Türkiye Kapsamında Değerlendirilmesi, Sosyal Politika Çalışmaları Dergisi, Yıl.18, Sayı.41. 
Şenol, V., Avsar, E., Akca, R.P., Argun, M., Avsaroğulları, L., and Kelestimur, F. (2015), Assessment of Mobbing Behaviors Exposed by the Academic Personnel Working in a University, in Turkey, Journal of Psychiatry, Volume $18 \bullet$ Issue $1 \bullet$ Psychiatry-14131.

The Global Gender Report 2006-2018, World Economic Forum Geneva, Switzerland.

Tınaz, P. (2006), İşyerinde Psikolojik Taciz (Mobbing), Çalışma ve Toplum, 2006/4, pp. 13-28.

Tomic, M.A. (2012), Mobbing: The Incidence of Mobbing Activities and Difference Regarding Workplace and Gender, Original scientific paper UDC 658.310.42:364.635; 005.962:364.634.4, Vol. 9 (1) 2012: Pp. 243-252.

Yanık, O. (2018), Mağdurların Yıldırmaya Karşı Agresif Açıdan Tepki Göstermesi ile Tepkisiz Kalmasının Altında Yatan Bireysel ve Çalışma Hayatına İlişkin Faktörler, Business and Economics Research Journal Vol. 9, No. 2, pp. 395-411 doi: 10,20409/berj.2018.112.

Yaşlıoğlu, M.M.(2017), Sosyal Bilimlerde Faktör Analizi ve Geçerlilik: Keşfedici ve Doğrulayıcı Faktör Analizlerinin Kullanılması, İstanbul Üniversitesi Iş̧letme Fakültesi Dergisi, Vol/Cilt: 46, Special Issue/Özel Sayı, 74-85 ISSN: 1303-1732 - http://dergipark.ulakbim.gov.tr/iuisletme.

Zeher, D.B., (2011), Gender Discrimination at Work: Connecting Gender Stereotypes, Institutional Policies, and Gender Composition of Workplace, Gender and Society, Volume: 25 issues: 6, page(s): 764-786, https://doi.org/10.1177/0891243211424741. 